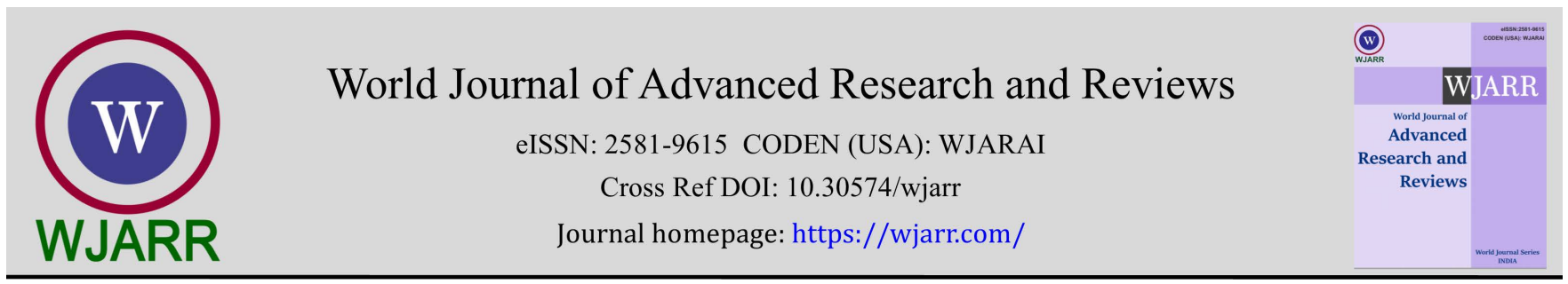

(REVIEW ARTICLE)

Check for updates

\title{
Convalescent plasma therapy for COVID-19
}

Heena Bholaram Choudhary *, Rohan Rajkumar Patekar *, Akshita Pramod Jain, Pratiksha Davkare, Samkit Dilip Soni, Shreyans Pravin Chorbele and Sachin Devidas Rede

Department of Pharmaceutics, SJVPM Rasiklal M. Dhariwal Institute of Pharmaceutical Education and Research; Chinchwad, Pune-411019, MH- India.

World Journal of Advanced Research and Reviews, 2021,11(03), 192-200

Publication history: Received on 16 August 2021; revised on 18 September 2021; accepted on 20 September 2021

Article DOI: https://doi.org/10.30574/wjarr.2021.11.3.0399

\begin{abstract}
The outbreak of severe acute respiratory syndrome COVID-19 caused by SARS-CoV-2 in China represents a significant threat to global health. Unfortunately, effective therapeutic drugs and vaccines to cure SARS-CoV-2 are still lacking. Convalescent Plasma therapy which induces passive immunization seems a successful treatment for COVID-19 patients and also proves to be of huge value in terms of saving the severely ill patient. Plasma therapy acts by Blocking the Virus (Neutralization), Enhancing Phagocytosis (Opsonization), Immune System Activation (Complement Activation), and finally killing Virus (Antibody-Dependent Cell-mediated Cytotoxicity). Food and Drug Administration (FDA) of the United States was also given the stamp of approval for use of plasma therapy on 23 August 2020. In this review, we introduced the effective level of antibodies, potential mechanisms of CPT, WHO criteria for donating the plasma as well as future uncertainties of convalescent plasma therapy in the treatment of COVID-19 patients.
\end{abstract}

Keywords: Convalescent plasma therapy; COVID-19; Neutralization; Passive immunization; Complement Activation

\section{Introduction}

SARS-CoV-2 is a large and enveloped single-stranded RNA virus that belongs to the family Coronavirinae that are usually presented in humans, which initially caused enzootic infections. There are four viruses (HKU1, OC43, 229E, and NL63) that are prevalent in humans, causing only mild to moderate upper respiratory symptoms, similar to the common cold in immunocompetent recipients. The remaining three strains MERS-Co-V, SARS-CoV-1, and the newly discovered SARSCoV-2 can cause fatal pneumonia which mainly disturbed the respiratory system of humans. Since 1890, Convalescent plasma therapy is passive antibody therapy. Treatment that has been done for coronavirus are serum therapy: Serum is liquid plasma without fibrinogen which kills the virus by using the antibodies from the recovered patient, Neutralizing antibody therapy: In this antibodies block the pathogen by neutralizing, Adoptive immunotherapy: A type of immunotherapy in which $\mathrm{T}$ cells are given to a patient to fight against the disease, Nanomedicine: By using nanoparticle antigen is introduced in the human body to develop antibodies, Decoy Biomolecules: They bind and trap the coronavirus as well as stop multiplication of cells in the body, Anti-viral Drugs (Ribavirin, Favipiravir, lopinavir). They increase the resistance of the cell to the virus and suppressed the virus adsorption in the cell [3].

\section{Convalescent Plasma therapy}

In the pandemic of diphtheria caused by Corynebacterium diphtheria, Emil Von Behring a German physiologist discovered the serum therapy in that experiment. He went on to become the first person to receive the Nobel Prize in the field of medicine [4]. Plasma therapy is the treatment for COVID-19 when any harmful bacteria or virus-like SARS-

\footnotetext{
* Corresponding author: Heena Bholaram Choudhary and Rohan Rajkumar Patekar

Department of Pharmaceutics, SJVPM Rasiklal M. Dhariwal Institute of Pharmaceutical Education and Research; Chinchwad, Pune411019, MH- India.

Copyright (C) 2021 Author(s) retain the copyright of this article. This article is published under the terms of the Creative Commons Attribution Liscense 4.0.
} 
CoV-2 enters the body. He observed that serum obtained from a rabbit infected with the disease diphtheria was effective in the treatment of diphtheria infection.

Convalescent plasma therapy involves the process of transfusion of a protein called antibodies from the person who has recovered from COVID-19. The neutralization of invading pathogen involved in the therapy is that blood of the recovered patient is rich in antibodies that are needed to compete COVID-19. Antibodies are proteins having Y- shape, produced by the human body utilize by the immune system to identify and neutralize foreign microbes such as bacteria as well as viruses. Passive antibody administration involves the transfer of already formed antibodies and is the only effective strategy that gives immediate protection to susceptible individuals [5]. Mostly, high-titer neutralizing antibody Convalescent plasma therapy is used to maximize biologic activity. When any harmful bacteria or virus-like SARS-CoV2 enters the body. The body tries to destroy it and our immune system has different kinds of warriors inside the body and among them are antibodies [6]. Food and Drug Administration (FDA) of the United States was also given the stamp of approval for use of plasma therapy on 23 August 2020. In India, States like Delhi (20 April 2020), Maharashtra (25 April 2020), Punjab (13 June 2020), Kerala (15 June 2020), and most of the others have already started using Convalescent plasma therapy as a treatment for severely ill COVID-19 Patients [7, 8]. The body generates a specific antibody to fight a particular invader like the antibody for COVID-19 will be different from the antibody for the specific Ebola virus. Being specific in nature antibodies are very effective in fighting virus-like coronavirus. But the body takes time to release these antibodies, hence the virus gets enough time to take over to spread itself more and more and the person's health becomes worst. Today, Convalescent plasma therapy is being seen as a potential treatment for severely ill patients [9].

\subsection{Convalescent Plasma Therapy}

Table 1 Summary of Clinical outcomes following treatment with the convalescent plasma therapy.

\begin{tabular}{|c|c|c|c|c|c|c|}
\hline $\begin{array}{l}\text { SR. } \\
\text { No. }\end{array}$ & $\begin{array}{l}\text { Name of } \\
\text { Disease }\end{array}$ & Year & $\begin{array}{l}\text { Name of } \\
\text { the } \\
\text { Country }\end{array}$ & $\begin{array}{l}\text { Effectiveness of } \\
\text { the disease }\end{array}$ & $\begin{array}{l}\text { Any Official } \\
\text { Approval }\end{array}$ & Mechanism of Action \\
\hline 1. & $\begin{array}{l}\text { Spanish Flu } \\
\text { (Influenza A } \\
\text { H1N1 virus) } \\
{[10][11]}\end{array}$ & 1918 & $\begin{array}{l}\text { United } \\
\text { States }\end{array}$ & $\begin{array}{lr}\text { Absolute } & 21 \% \\
\text { mortality } & \text { and } \\
\text { morbidity have } & \text { haved reduced. }\end{array}$ & $\begin{array}{l}\text { Approved by } \\
\text { U.S.FDA }\end{array}$ & $\begin{array}{l}\text { The pathogen is } \\
\text { neutralized by Anti- } \\
\text { influenza antibodies in } \\
\text { the blood product. }\end{array}$ \\
\hline 2. & $\begin{array}{l}\text { Influenza } \\
\text { pandemic } \\
\text { (influenza A } \\
\text { H1N1 virus) } \\
{[12]}\end{array}$ & $\begin{array}{l}2009- \\
2010\end{array}$ & Hongkong & $\begin{array}{l}\text { Effectively reduced } \\
\text { the viral load and } \\
\text { dampened the } \\
\text { cytokine response } \\
\text { by reducing } \\
\text { approximately } \\
21.5 \% \text { mortality. }\end{array}$ & $\begin{array}{l}\text { Approved by } \\
\text { WHO }\end{array}$ & $\begin{array}{l}\text { Neutralizing and non- } \\
\text { neutralizing antibodies in } \\
\text { the plasma facilitate viral } \\
\text { entry into FC receptor- } \\
\text { bearing antigen- } \\
\text { presenting cells such as } \\
\text { macrophages and B } \\
\text { lymphocytes; these cells } \\
\text { are not permissive to the } \\
\text { growth of the influenza } \\
\text { virus. }\end{array}$ \\
\hline 3. & Ebola [13] & 2013 & $\begin{array}{l}\text { African } \\
\text { Countries }\end{array}$ & $\begin{array}{l}\text { The mortality rate } \\
\text { is reduced to } 40 \text { - } \\
60 \%\end{array}$ & $\begin{array}{l}\text { Approved by } \\
\text { WHO }\end{array}$ & $\begin{array}{l}\text { Convalescent plasma is a } \\
\text { source of Anti-EVD } \\
\text { antibodies which have } \\
\text { the advantage of being } \\
\text { active against the } \\
\text { circulating strain. }\end{array}$ \\
\hline 4. & $\begin{array}{l}\text { MERS (Middle } \\
\text { East } \\
\text { Respiratory } \\
\text { Syndrome) } \\
{[14]}\end{array}$ & 2015 & $\begin{array}{l}\text { Saudi } \\
\text { Arabia }\end{array}$ & $\begin{array}{l}\text { Transfused patient } \\
\text { overall mortality } \\
\text { rate: } 0 \%(0 / 3)\end{array}$ & $\begin{array}{l}\text { Approved by } \\
\text { central for } \\
\text { disease } \\
\text { control and } \\
\text { prevention. } \\
\text { (CDC) }\end{array}$ & $\begin{array}{l}\text { MERS virus is neutralized } \\
\text { by the antibodies present } \\
\text { in the convalescent } \\
\text { plasma. }\end{array}$ \\
\hline
\end{tabular}




\begin{tabular}{|l|l|l|l|l|l|l|}
\hline 5. & $\begin{array}{l}\text { SARS-CoV-2 } \\
\text { [15] }\end{array}$ & 2019 & $\begin{array}{l}\text { Wuhan, } \\
\text { China }\end{array}$ & $\begin{array}{l}\text { The severely ill } \\
\text { patient can be } \\
\text { successfully } \\
\text { treated with the } \\
\text { CPT. }\end{array}$ & $\begin{array}{l}\text { Approved by } \\
\text { FDA }\end{array}$ & $\begin{array}{l}\text { Neutralization } \\
\text { invading pathogen by } \\
\text { toxicity. }\end{array}$ \\
\hline
\end{tabular}

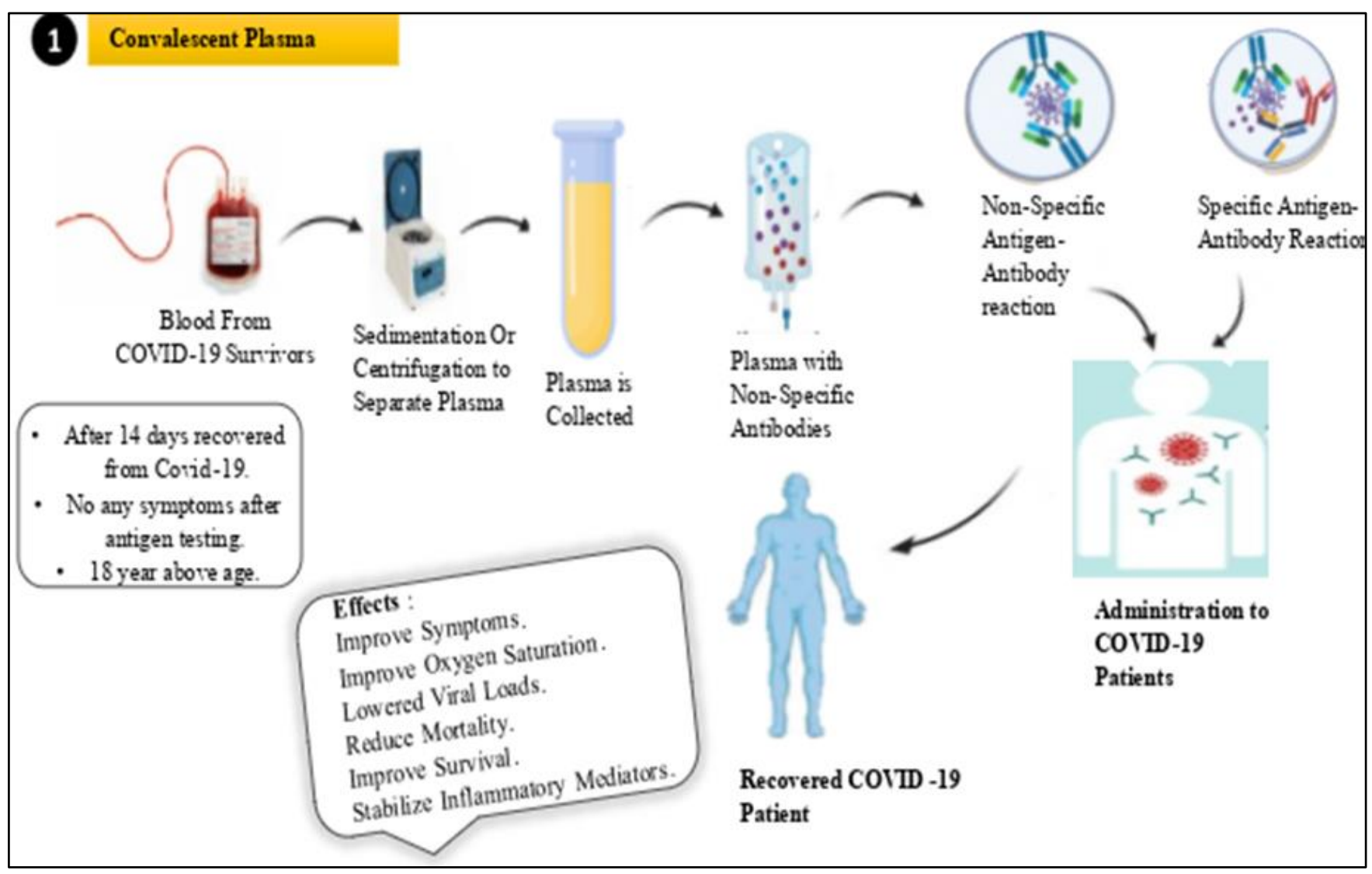

Figure 1 This figure illustrates the process of donating the plasma after fulfilled the standard criteria. Also gives the idea about the effectiveness of plasma therapy [33]

\section{Clinical trials for evaluating the safety and efficacy of human Anti-SARS-CoV-2 Convalescent plasma}

\subsection{As per the Clinical Trial Registry of India (Registration no.- CTRI/2020/04/024775) [16]}

An open-label, parallel-arm, phase II, multicenter, randomized controlled trial (placid trial), setting at 39 public and private hospitals across India involving 464 adults ( $\geq 18$ years) admitted to hospital (screened 22 April to 14 July 2020) with confirmed moderate COVID-19, 235 participants were assigned to convalescent plasma (2 doses of $200 \mathrm{~mL}$ convalescent plasma, transfused 24 hours apart) with the best standard of care (intervention arm) and 229 participants to the best standard of care only (control arm). The progression to severe disease or all-cause mortality at 28 days after enrolment occurred in $44(19 \%)$ participants in the intervention arm and $41(18 \%)$ in the control arm (risk difference 0.008 (95\% confidence interval -0.062 to 0.078 ); risk ratio $1.04,95 \%$ confidence interval 0.71 to 1.54 ). Thus, convalescent plasma was not associated with a reduction in progression to severe covid-19 or all-cause mortality.

\subsection{As per the U.S National Library of Medicine (Registration No. - CTRI/2020/025NCT04372979) [17]}

A triple-blinded, parallel-arm, phase 3, randomized, controlled clinical trial to tests the efficacy of convalescent plasma transfusion therapy in the early care of COVID-19 hospitalized patients outside intensive care units started on 14th Sept 2020, is expected to be completed on June 2021 with primary measure outcome survival time without needs of a ventilator and secondary measure outcome as morbidity, mortality, length of stay, effect on viral pharyngeal specimen clearance, effect on viral blood specimen clearance, effect on hemostasis disorders, the kinetics of appearance of 
neutralizing antibodies, transfusion effect, transfusion biological Inflammation effect, transfusion hemovigilance, decrease in the consumption of antibiotics.

\section{WHO Guidelines and Criteria Donation of Plasma [18]}

CPT donor must be tested for neutralizing antibody which are assessed with a plaque reduction neutralization test. This requires viable isolate, replication-competent cell lines. They weighed at least 110 pounds or 50 kilograms and pass a medical inspection. The process of donating plasma is similar to Blood Donation Bank in this method plasma is extracted from the blood and the remaining cells are returned to the donor's body. The donor age should be between 18 to 60 years old. The process of extracting plasma from the blood is known as plasmapheresis. The blood group of the donors matched with the blood group of the receiver and it is also checked that the plasma of the donor has a sufficient amount of antibodies in it. As per the U.S. Food and Drug Administration, the donor can donate plasma twice a week and like the proper blood donation which is once in three months. A single donor can donate $400 \mathrm{ml}$ of plasma at a time $200 \mathrm{ml}$ is sufficient to treat one COVID-19 patient. Hence plasma donated by a single person who was recovered from COVID-19 can help two people to recover [32].

Table 2 Different tests performed in COVID-19

\begin{tabular}{|c|c|c|c|}
\hline Test Name & Reason for doing test & $\begin{array}{l}\text { Criteria and standard } \\
\text { limit of acceptance }\end{array}$ & $\begin{array}{l}\text { Cost of the test } \\
\text { as per India }\end{array}$ \\
\hline $\begin{array}{l}\text { Haematocrit } \\
\text { test: }[19] \\
\text { (PCV test) } \\
\text { Packed Cell } \\
\text { Volume Test. }\end{array}$ & $\begin{array}{l}\text { The test measures the blood protein in RBCs } \\
\text { (hemoglobin). RBCs help to carry oxygen } \\
\text { from the lungs to the rest of the body. } \\
\text { Haematocrit levels that are too high or too } \\
\text { low can indicate a blood disorder, } \\
\text { dehydration. }\end{array}$ & $\begin{array}{l}\text { Haematocrit: } \\
\text { Male: } 38.3-48.6 \% \text { Female: } \\
\text { 35.5-44.9\% Haematocrit } \\
\text { below normal range. }\end{array}$ & $\begin{array}{l}\text { PCV test: } \\
\text { Rs. } 160-300 \\
\text { varies as per } \\
\text { requirement. }\end{array}$ \\
\hline $\begin{array}{l}\text { Plasma Protein } \\
\text { Test [20][21] }\end{array}$ & $\begin{array}{l}\text { Tests are used to measure the amounts of } \\
\text { specific proteins in the blood. Total protein } \\
\text { levels may be changes in the case of disease } \\
\text { like bone marrow disorders, edema. }\end{array}$ & $\begin{array}{l}\text { The normal level of serum } \\
\text { proteins approximately } 6 \\
\text { to } 8 \mathrm{~g} / \mathrm{dl} \text {. }\end{array}$ & $\begin{array}{lr}\text { Plasma } & \text { Protein } \\
\text { Test- } & 200- \\
\text { 500Rs } & \end{array}$ \\
\hline $\begin{array}{l}\text { Test for HBsAg } \\
\text { (Hepatitis B } \\
\text { surface antigen } \\
\text { test) [22][23] }\end{array}$ & $\begin{array}{l}\text { Hepatitis B surface antigen test is performed } \\
\text { to ensure the presence of hepatitis virus } \\
\text { infection. }\end{array}$ & $\begin{array}{l}\text { (anti-HBs), a level less } \\
\text { than } 5 \mathrm{mIU} \text { is negative and } \\
\text { more than } 12 \mathrm{mIU} \text { is } \\
\text { considered protective. }\end{array}$ & $\begin{array}{l}\text { Hepa scan test: } \\
\text { Rs. } 2000\end{array}$ \\
\hline $\begin{array}{l}\text { Anti-HIV test } \\
\text { (ELISA test) }[24]\end{array}$ & $\begin{array}{l}\text { An anti-HIV test is performed for checking the } \\
\text { infection HIV. i.e. AIDS }\end{array}$ & $\begin{array}{l}\text { Rapid Screen test: if the } \\
\text { no. is less than } 1.0 \text { test is } \\
\text { negative, while no greater } \\
\text { than } 1.0 \text { test is positive. }\end{array}$ & $\begin{array}{l}\text { Rapid screen } \\
\text { anti-HIV test- } \\
\text { 1000-5000Rs. }\end{array}$ \\
\hline $\begin{array}{l}\text { Anti-HCV test } \\
\text { (Hepatitis } \quad \text { C } \\
\text { virus) [25] }\end{array}$ & $\begin{array}{l}\text { An Anti-HCV test has checked the presence of } \\
\text { Hepatitis C virus infection. }\end{array}$ & $\begin{array}{l}\text { A blood test is used to } \\
\text { detect the presence of a } \\
\text { virus in the body. }\end{array}$ & $\begin{array}{l}\text { Anti-HCV test: } \\
\text { Rs. 500-1000 }\end{array}$ \\
\hline
\end{tabular}

\subsection{Efficient Levels of Antibodies [26]}

The levels of antibodies are useful for vaccines and this is also helpful to test for Convalescent Plasma. In the human being, there are various levels of immunoglobulin-G that are either given from outside or are produced inside by triggering the immune system by vaccination or produced by the disease itself. In the SARS-CoV-2, it is necessary to find out the level of antibodies needed fora better response.

In the Experiment, they infected the number of rhesus macaque monkeys with SARS-CoV-2 after the infection they collected their plasma and the plasma contain polyclonal antibodies, that are not monoclonal but polyclonal because the antibodies that are generated going to be targeted on various parts of SARS-CoV-2. They took that plasma and then from that plasma, they extracted various immunoglobulin-G antibodies and concentrated them. They injected various levels of antibodies in rhesus monkeys and then measured the protective level of antibodies. The first part of the experiment was only done to be able to collect the polyclonal antibodies from the convalescent plasma. So they did not give the Convalescent Plasma itself because the convalescent plasma did not have the amounts that are wanted to give 
in various doses. Then they concentrated and collected them separately hence they can control various doses in various animals. Now next part of an experiment that they did on day zero, they infected a few rhesus macaque monkeys with SARS-CoV-2 and the way to infect was they would do inject the virus in their nasal cavity and their mouth and some cranial cavity and so on. So they injected them. Once they had injected them on day zero, on day 1 you are not expecting them to make their antibodies. Their antibodies would start forming from 7 to 14 days and beyond. Therefore, on the 2nd day, they started injecting antibodies that they had collected from other rhesus monkeys in the first phase of the experiment, and here is what they did for in one group they injected 250 milligrams per kilogram of the antibodies. So in another group, they injected 2.5 milligrams per kilogram. That is $10 \mathrm{X}$ lesser and then in another group, they injected nothing. So these were three groups. They were all infected on day zero. On day 1 they got the antibodies then they started seeing the response of the SARS-CoV-2 in them to see how much of the SARS-CoV-2 was replicating.

The experimental study concluded that, those monkeys that had not received the antibody at all and were infected. They started developing or started having the virus in their bronchioloalveolar lavage. So bronchial alveolar lavage in the monkeys that were not given the antibodies 7 to 10 days they had the virus and 10 to 14 days they had the virus in their nasal area than those that were 2.5 milligrams per kilogram that were given immunoglobulin. So in these monkeys, they saw that for three to ten days bronchiole alveolar lavage shows the virus. Hence, the virus did produce in them but the production was slightly different and then in the nasal from 7 to 10 days instead of 10 to 14 days. Then there was some protection not significant protection and then those monkeys that had 250 milligrams per kilogram bodyweight of immunoglobulin had no SARS-CoV-2 replicated at all in the lungs or the nose so they were protected. So we give 250 milligrams per kilogram from outside now that means once that antibody is dissolved in the body tissue and the level that is established inside the fluid is used to understand the level of antibodies required for convalescent plasma therapy. If it neutralizing antibodies so when the antibodies are produced against the COVID-19 the antibodies are of various types [27].

\subsection{Role of cellular Immunity [28]}

When we give immunoglobulins and even if the levels are low however if the CD8 $\mathrm{T}$ cells are competent then the monkey had the protection against SARS-CoV-2. The reason for that is CD8 cells were functioning. So here conclude that monkeys that had competent CD8 cells were able to work and protect themselves even when the antibody levels were low that means even when B cells were not functioning that much and CD8 cells function more the person handles SARS-CoV-2 with fewer symptoms. They also took some monkeys and they had deleted their CD8 cells so they sent in antibodies that would go and kill the CD8 cells from them. So that made them immunocompromised by removing themselves and then they give them the antibodies and made them infected as well and these monkeys are not able to handle the virus that well as the one competent CD8 cells that are a huge deal.

\subsection{Mechanism of Plasma Therapy [30]}

\subsubsection{Neutralization}

(Blocking of Pathogen / Microbial Toxin): In neutralization, antibodies bind to their specific microbes or microbial toxins. These antibodies block pathogen entry into the cells and utilize their infectivity. Microbes and microbial toxins bind to the surface molecules of the host cell. By this binding, they also gain entry into the cell. When antibodies to these microbes or microbial toxins are present in the body these antibodies bind to them and thus block them or in other words utilize their interactivity these neutralized microbes are finally eliminated by the phagocytosis process does neutralization discourage preventing the pathogen from initiating and infection neutralization is effective mechanism against viruses bacterial toxins insects and snake venom.

\subsubsection{Opsonization}

(Enhances the process of Phagocytosis): Antibodies coats the surface of the pathogen by binding to specific antigen determinants here antibodies are acting as abstinence these bound antibodies are recognized by the phagocytic cells. Phagocytic cells have specific FC receptors on the surface once PACA sites find the antibodies via FC receptor these pathogens are eliminated by phagocytosis so in this mechanism antibody acts as opsin in which forms a bridge between the pathogen and Phagocyte.

\subsubsection{Complement Activation}

(The Classical Pathway): We know that complement refers to a set of about 20 proteins in the blood plasma a pathogen coded by antibodies also initiate the classical pathway of complement activation was activated this pathway leads to the destruction of the pathogens by a various mechanism such as membrane attack complex, opsonization, and inflammation. 


\subsubsection{Antibody-Dependent Cell-mediated Cytotoxicity}

(Killing Infected cells / Pathogen by cytotoxic Chemical): To understand this mechanism considered these two cases. First, when there is an intracellular interaction let's say a virus infected a cell. The second case is when the invading pathogens are too large for example, parasitic worms. In both these cases, phagocytosis cannot eliminate the pathogen since the target cannot internalize in such cases a different strategy is used by our immune system. This involves antibodies, antibodies coat the target seller of the parasite. infected cells display foreign antigens derived from the virus on the plasma membrane. Antibodies bind to this antigen the FC region of these antibodies is recognized by glucosides having to kill cytotoxic function. An example of such cells is natural killer cells that used eosinophils. These cells have specific FC receptors on the surface. They bind these antibodies by the receptors. This binding results in the degradation of the cytotoxic cells. Cytotoxic chemicals are released which disturb the antibody side having specific FC receptors for these bound antibodies. This results in the lysis of the pathogen or target. This whole mechanism of pathogen Elimination is known as antibody-dependent cell-mediated cytotoxicity. It is antibody-dependent because the antibody forms the bridge between the pathogen or target cell in the effector leucocyte. The term cytotoxicity represents that the target is killed by the cytotoxic chemical released by leukocytes specialized for this function. ADCC can be defined as the process of killing antibody-coated target cells by certain leukocytes having specific FC receptors for these bound antibodies.

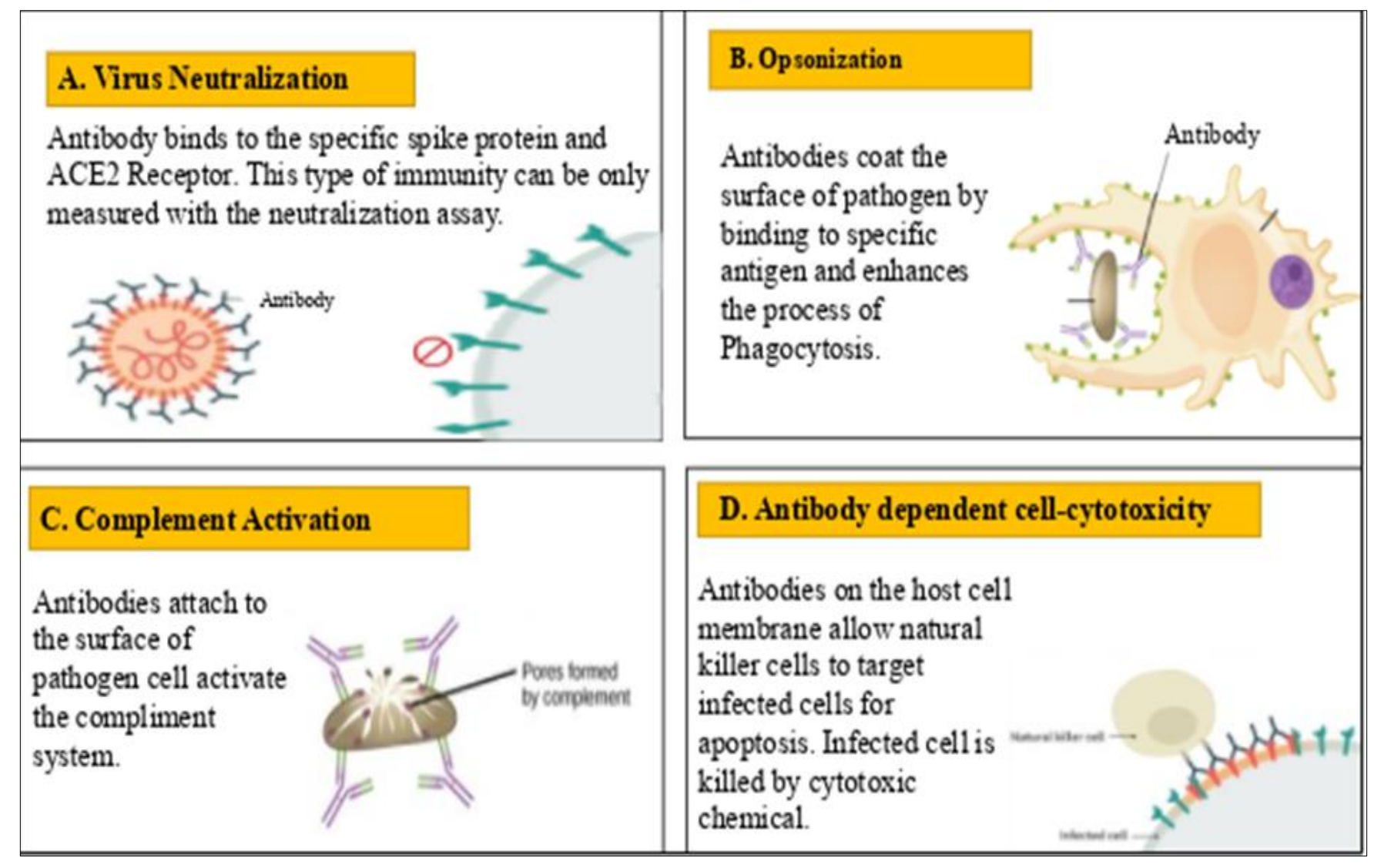

Figure 2 Potential mechanisms of action of anti-severe acute respiratory syndrome coronavirus 2 (SARS-CoV-2) antibodies in COVID-19. This figure shows the first attachment of SARS-CoV-2 to the membrane of the host cell followed by penetration, bursting of the cell membrane. After those antibodies in the host cell kill the infected cell with cytotoxic chemicals [30].

\subsection{Storage of plasma}

Plasma components should be frozen within a specified period after collection. Whole blood and RBCs should be refrigerated (at $1-6^{\circ} \mathrm{C}$ ) and platelets should be stored at $20-24{ }^{\circ} \mathrm{C}$ under agitation, at $-18^{\circ} \mathrm{C}$ for a year, or $-65{ }^{\circ} \mathrm{C}$ for seven years. If the process stopped at once, it should be kept at $1-6{ }^{\circ} \mathrm{C}$ for approximately 5 days [33]. Under these conditions, bacterial contamination has not been a problem. According to European pharmacopeia if the temperature of the plasma is between $-20^{\circ} \mathrm{C}$ and $-15^{\circ} \mathrm{C}$ for a maximum of 72 hours or if it is above $-15^{\circ} \mathrm{C}$ (but colder than $-5^{\circ} \mathrm{C}$ ) in no more than one occurrence, the Plasma can be used for fractionation. So, maintaining a constant Storage temperature of $-20^{\circ} \mathrm{C}$ or colder is the best approach to ensure a consistent and optimal plasma quality [35]. 


\section{Conclusion}

Plasma therapy is a preventive measure and is used for critically ill patients only it provides passive immunization unlike a vaccine against a particular infection that is given to a person the immune system starts producing specific antibodies. These antibodies leave a memory in the cells to fight any future infection on a later date when the vaccinated person is infected by the actual Germs or viruses the immune system neutralizes infection by releasing the required antibodies. While the vaccine provides such lifelong immunity the effect of plasma therapy last only till the antibodies ingested into the infected person remain in the bloodstream therefore the protection given by the plasma therapy is only temporary so plasma therapy does not seem to be full-proof therapy but it has helped in treating some of the critically ill covid-19 patients across the global welfare from COVID-19.

\section{Compliance with ethical standards}

\section{Acknowledgments}

We are thankful to Dr. Sanjay G. Walode, Dr. Mithun Rudrapal, Mr. Sachin Rede, for providing us best informative and innovational domain so that we could complete our review article successfully.

\section{Disclosure of conflict of interest}

We have no conflicts of interest regarding this investigation.

\section{References}

[1] Ripoll, Juan G, et al. Convalescent plasma for infectious diseases: Historical framework and use in COVID-19. Clinical Microbiology Newsletter.15 Feb 2021; 43(4): 23-32.

[2] Lamberghini, Flavia, Fernando D Testai. COVID-19 fundamentals. The Journal of the American Dental Association. 2021: 152(5): 354-363.

[3] Liu, Sean TH., et al. "Convalescent plasma treatment of severe COVID-19: A propensity score-matched control study." Nature medicine. 2020; 26(11): 1708-1713.

[4] NEWS/ The Peculiar 100-Plus -Year -History of Convalescent plasma therapy by Jillian mock Smithsonian magazine. 1 September 2020.

[5] Heena B Choudhary, Rohan R Patekar et al. "COVID-19 Vaccines: Systematic review” World Journal of Advanced Research and Reviews (2021) Vol.10 (01); 143-155. DOI: doi.org/10.30574/wjarr.2021.10.1.0118

[6] NDTV News/ "What are Antibodies? And How they help fight COVID-19?" August 18, 2020.

[7] Velavan TP, Meyer CG. The COVID-19 epidemic. Trop Med Int Health. 2020 Mar;25(3):278-280.

[8] Duan Kai, et al. Effectiveness of convalescent plasma therapy in severe COVID-19 patients. Proceedings of the National Academy of Sciences. 2020; 117(17): 9490-9496.

[9] Arturo Casadevall, Liise-anne Pirofski. The convalescent sera option for containing COVID-19. JCI The Journal of Clinical Investigation. April 2020; 130: 1545-1546.

[10] Luke, Thomas C., et al. "Meta-analysis: convalescent blood products for Spanish influenza pneumonia.

[11] Xu, Zhiheng, et al. Efficacy of convalescent plasma for the treatment of severe influenza. Critical Care. 2020; 24(1): 1-7.

[12] Hung, Ivan FN, et al. Convalescent plasma treatment reduced mortality in patients with severe pandemic influenza A (H1N1) 2009 virus infection. Clinical Infectious Diseases. 2011; 52(4): 447-456.

[13] Sahr F, Ansumana R, Massaquoi TA, Idriss BR, Sesay FR, Lamin JM, et al. Evaluation of convalescent whole blood for treating Ebola Virus Disease in Freetown, Sierra Leone. J Infect 2017; 74: 302-9.

[14] Ko JH, Seok H, Cho SY, Ha YE, Baek JY, Kim SH, et al. Challenges of convalescent plasma infusion therapy in Middle East respiratory coronavirus infection: a single-center experience. Antivir Ther. 2018; 23: 617-22.

[15] Piyush R, Rajarshi K, Khan R, Ray S. Convalescent plasma therapy: a promising coronavirus disease 2019 treatment strategy. Open Biol. 2020; 10: 1-2. 
[16] Agarwal A, Mukherjee A, Kumar G, Chatterjee P, Bhatnagar T, Malhotra P; PLACID Trial Collaborators. Convalescent plasma in the management of moderate covid-19 in adults in India: open label phase II multicentre randomised controlled trial (PLACID Trial). BMJ. 2020 Oct 22;371.

[17] Oliveira FA, Nucci MP, Rego GN, Alves AH, Marti LC, Nucci LP, et al. Convalescent plasma therapy in COVID-19 critically ill patients during advanced phases of clinical trials and their preliminary results. einstein (São Paulo). 2021; 19: eRW6186.

[18] Requirements for the Collection, processing and Quality control of blood, blood components and plasma derivatives (Requirement for biological substances No.27, revised 1988) In the WHO Committee on Biological Standardization, Thirty-ninth Report. Geneva, World Health Organization, 1989, Annex 4 (WHO Technical Report Series, no.786).

[19] Winnecke, Gitte. Hematocrit-a review of different analytical methods. Radiometer Medical ApS. 2004.

[20] Kristeen Churney. Plasma protein test, Healthline Available From: https://www.healthline.com/health/plasmaprotein-tests

[21] Kuusela P, Saraswat M, Joenva"a"ra" S, Kaartinen J, Ja"rvinen A, Renkonen R. (2017) Changes in plasma protein levels as an early indication of a bloodstream infection. PLoS ONE. 2017; 12(2): e0172987.

[22] Ali Amini, Olivia Varsaneux, Helen Kelly. Diagnostic accuracy of tests to detect hepatitis B surface antigen: a systematic review of the literature and meta-analysis. BMC infectious disease. 2017; 17(Suppl 1): 698.

[23] Charles Daniel. Hepatitis B Surface Antigen Test (HBsAg). Verywellhealth. 09 April 2020.

[24] Gauthier DK, Turner JG. Anti-HIV antibody testing: procedures and precautions. Am J Infect Control. 1989 Aug; 17(4): 213-25.

[25] Ekta Gupta, Meenu Bajpai, Aashish Choudhary. Hepatitis C virus: Screening, diagnosis, and interpretation of laboratory assay. Asian Journal of Transfusion Science. 2014; 19-25.

[26] Drs. Joyner, Carter, Senefeld, Drs. Paneth, Fairweather, Wright, Casadevall. Convalescent Plasma Antibody Levels and the Risk of Death from Covid-19. The new England journal of medicine. 18 March 2021; 384(11).

[27] Katherine McMahan, Jingyou Yu, et al. Correlates of protection against SARS-CoV-2 in rhesus macaques. Nature research. February 2021; 590(25): 630-635.

[28] Iqbal, Henna. The importance of cell-mediated immunity in COVID-19-An opinion. Medical Hypotheses. 2020; 143: 110152.

[29] Evan M. Bloch et al. Deployment of convalescent plasma for the prevention and treatment of COVID-19. JCI The Journal of Clinical Investigation. 2020; 130(6): 2757-2765.

[30] Weiqian Dai, Haihui Gu, Sha Hao. Potential benefits, mechanisms, and uncertainties of convalescent plasma therapy for COVID-19. Blood Science. 71-72.

[31] NivedithaDevasenapathy MBBS MSc, Zhikang Ye MPharm, Mark Loeb MD MSc Efficacy and safety of convalescent plasma for severe COVID-19 based on evidence in other severe respiratory viral infections: a systematic review and meta-analysis. CMAJ. 6 July 2020; 192: E745-55.

[32] Valeria Selvi Convalescent Plasma: A Challenging Tool to Treat COVID-19 Patients-A Lesson from the Past and New Perspectives. BioMed Research International. 23 September 2020; Article ID 2606058, 8.

[33] Khan Sharun. Antibody-based immune-therapeutics and use of convalescent plasma to counter COVID-19: advances and prospects. Taylor and Francis group, EXPERT OPINION ON BIOLOGICAL THERAPY. 2020; 20(9): 1033-1046.

[34] Rosamond Barreneche. How are blood bags Stored? FINDANYANSWER. 1 July 2020.

[35] John R. Hess Conventional blood banking and blood component storage regulation: opportunities for improvement. University of Maryland, Baltimore, U.S.A. Blood Transfus. 2010; 8 Suppl3: s9-s15.

[36] Trupti Wadekar, Sushant Terdale, Onkar Sumant. Plasma Fractionation market by product (Albumin, Immunoglobulins, Coagulation Factor VII and Coagulation Factor IX) and sector (Public Sector and Private sector): Global Opportunity Analysis and Industry Forecast, 2020-2027, Allied Market Research. March 2021; 202. 
[37] Basavraj Nagobaa, Ajay Gavkarea, Nawab Jamadar. Positive aspects, negative aspects, and limitations of plasma therapy with special reference to COVID-19. Journal of infection and public health.

[38] Dhanase karan S, Vajravelu LK, Venkatesalu V. Risk-benefit analysis on the clinical significance of convalescent plasma therapy in the management of COVID-19. Postgraduate Medical Journal Published Online First. 17 August 2020.

[39] NDTV News, COVID-19 Plasma Therapy Shows Little Benefits In Patients In India, Study Finds. The study, published in British Medical Journal (BMJ) involved 464 adults with moderate COVID-19 who were admitted to hospitals in India between April and July 2020.

[40] NEWS/ India to explore Novel blood plasma therapy for COVID-19. The state Hindu BusinessLine, New Delhi. 10 April 2020. 